\title{
IMPACT OF ECOLOGICAL ENGINEERING ON THE TYPE AND POPULATION OF PESTS, NATURAL ENEMIES, AND YIELDS OF THE RICE
}

\author{
N. Usyati, Nia Kurniawati, \& Oco Rumasa \\ Indonesian Center for Rice Research \\ Jl. Raya IX Sukamandi, Ciasem Subang Jawa Barat 41256 \\ E-mail:n_usyati06@yahoo.co.id
}

Manuscript received: 7 April 2020. Revision accepted: 17 August 2020.

\begin{abstract}
Impact of ecological engineering on the type and population of pests, natural enemies, and yields of the rice. This study was performed to investigate the impact of the ecological engineering in the rice field on the crop damage caused by yellow stem borer, including it's type and population as well as its natural enemies and the yields of the rice. The study was conducted in farmer's fields in Subang District in the dry and the wet seasons. The research was arranged using Randomized Complete Block Design (RCBD) with 9 treatments and 3 replications. The observation was conducted on the crop damage caused by yellow stem borer, the type and the population of pests insect, its predator, and parasitoid as well as yields of the rice. The planting of flowering plants and crops showed inconsistent effect on the population of brown planthoppers, whitebacked planthoppers, and rice black bug. Moreover, it also not significantly impact the yellow stem borer. The planting of flowering plants and crops did not affect the rice yields. The parasitization level of the parasitoid was in ranged of 47.32 $50.47 \%$ (dry season) and 36.37-53.92\% (wet season). The neutral insect population was dominant at the beginning of planting (11-1743), meanwhile at the maximum tillering until the harvest was dominated by predators (9.33-131.33). The parasitoids were relatively contrasted on each stage of the rice plant.
\end{abstract}

Key words: ecological engineering, natural enemies, pests, rice yield

\section{INTRODUCTION}

Rice production are currently facing various obstacles and problems, including pest attacks. Based on the widespread of pest attacks in 2006, rice stem borer was on the first domonant pest which impacting 112,950 ha. The second domonant pest was rat, damaging 103,786 ha and the third domonant pest was brown planthopper which damaged 28,421 ha of rice fields (Dirjentan, 2007). However, in the 2009 and 2010 planting season, brown planthopper was dominant pest and invested several regions in Indonesia and caused high yield losses or crop failure (BBPOPT, 2010). During 2011 to 2013, the rice stem borer damage area was ranked first, especially in West Java. Based on 2015 field observations, the damage area of yellow rice stem borer in West Java was around 3.27-4.20\% while in East Java was lower (2.30-4.33\%). In 2016, the damage area due to rice stem borer in Indonesia was ranked $2^{\text {nd }}$ after rats, covering an area of 31,497 ha (Kusprayogie et al., 2016).

The farmers are still using insecticides to control rice pests. The application of insecticides is effective in controlling pests partially, but at the same time, it also kills natural enemies such as predators and parasitoids that hold the potential to control the pests biologically (Kartohardjono, 2011). Debach (1973) reminded that, excessive use of pesticides will result in biological explosion and disruption of the natural balance with various negative consequences. Therefore, to control these pests, it is recommended to do it ecologically.

Ecological pest control is a strategy to suppress the pest population as low as possible by utilise the relationship between insects and all aspects of their environment. The relationship is including the interactions of insect with the abiotic and biotic components. The abiotic components includes a place to live and climate, while the biotic component are plant and insect pests as well as the natural enemies and other competitors (Altieri et al., 2005).

Regarding ecological pest control efforts, some ecological engineering has been carried out such as the provision of organic material (Baehaki et al., 2003; Baehaki \& Djuniadi, 2004; Widiarta et al., 2006), cropping arrangements (paddy-paddy-2nd crop) (Herlinda, 2000), integrated planting of rice and crops 
(Baehaki \& Djuniadi, 2004; Baehaki, 2005), and planting cowpea, french bean and cluster bean as border crops in blackgram fields (Lokesh et al., 2017).

Ecological engineering by planting flowering plants such as Brassica juncea (Brassicaceae), Nasturtium indicum (Brassicaceae), and Cuphea microphylla (Lythraceae) intercropped with cabbage could increase the level of parasitism of Diadegma semiclausum on cabbage field (Ngatimin, 2002). In Malaysian, the practice of ecological engineering, through planting of flowering plants and practicing environmentally friendly agricultural was proven to increase arthropod biodiversity. The flowering plants serve as refugees and alternative food source for the arthropod to sustain in the environment (Amzah et al., 2018).

Flowering plants play a role in the development of pests and natural enemies. However, on the rice fields in Indonesia, information on this matter is not yet available. The purpose of this study was to determine the impact of ecological engineering to the type and populations of insect pests, natural enemies, and yields of rice.

\section{MATERIALS AND METHODS}

Research Sites. This study was conducted in the farmer's field in Subang, West Java, in one period of dry season and wet season.

Design of Experiment. This study was designed using RCBD (randomized complete block design) with 9 treatments and 3 replications. The treatments was: ASesamum orientale (L.) flower (Pedaliaceae); BWedelia trilobata (L.) (Asteraceae); C-corn; Dsoybean; E-combination of Sesamum orientale (L.) (Pedaliaceae) flowers with corn; F-combination of Wedelia trilobata (L.) (Asteraceae) flowers with corn; G-combination of Sesamum orientale (L.) (Pedaliaceae) flowers with soybeans; $\mathrm{H}$-combination of Wedelia trilobata (L.) (Asteraceae) flowers with soybeans; and I-control = without flowering plants and crops.

Flowering Plants and Crops Planting. Flowering plants and crops (corn, soybean, and sesame) were planted on the dike of farmer's field in an area of 0.25 ha without applying any insecticides and as a comparison, an area of 0.25 ha was control. The distance among the fields were $50 \mathrm{~m}$. The total area of land used for the research was $67,500 \mathrm{~m}^{2}(=7 \mathrm{ha})$. The rice variety used was Mekongga and crops used were Super Bee sweet corn, Grobogan soybean, and Sumberejo sesame.

The Population of Insect Pests and Natural Enemies. Pests and natural enemies were observed every 2 weeks, from 2 weeks after planting to 10 days before harvest. The observed variables were attack rate and the populations of pest, predator, and parasitoid. The attack rates and pest populations as well as predator populations were observed visually on 30 hills of rice plants per plot randomly.

Pest, predator, and parasitoid populations were observed by using a sweep net, yellow pan traping, and pitfall traps. A $38 \mathrm{~cm}$ in diameter sweep net was used by swing it 20 times for one sampling in each plot (Yaherwandi et al., 2007). Yellow pan traps were installed at 4 points on each plot. The traps were made of yellow plastic ( $20 \mathrm{~cm}$ in diameter) and the surface was filled with detergent. Pitfall traps were installed at 4 points on each plot. The traps were made of $450 \mathrm{~mL}$ plastic cups and installed by sink it in the ground so that the top surface was flat to the ground. The plastic cups were then filled with detergent. Yellow pan and pitfall traps were installed for 24 hours for each observation. The collected pests, predators, and parasitoids were then counted and identified to the family level.

The level of parasitism was observed by trapping using brown planthopper eggs which were in the stems of rice plants. For each plot, 10 of rice plants containing 1-day old brown planthopper eggs were installed. Trapping was carried out for 3 days in the field. The parasitized brown planthopper eggs were taken to the laboratory and maintained until the parasitoids appear. Parasitoid that appeared then observed its number, type, and calculated the level of parasitism.

Rice harvesting was done by harvesting the rice plants per plot $(0.25 \mathrm{ha})$. The harvesting was begins in the $3^{\text {rd }}$ row of rice groves from the edge of the plot and the grain yields were weighed as harvested dry grain.

The data obtained were analyzed by analysis of variance (ANOVA) and differences between treatments were evaluated by Duncan's multiple range tests at a $5 \%$ significance level using the SAS Version 6 program (SAS Institute, 1990).

\section{RESULTS AND DISCUSSION}

Damage Intensity by Yellow Rice Stem Borers. The damage intensity of yellow rice stem borers during the dry season was very low in all treatments. Meanwhile, in the wet season there was no attack by yellow rice 
stem borer. The intensity of yellow rice stem borer attack during the dry season and the wet season did not differ among treatments $(\mathrm{P}=0.2211$ - the dry season; $\mathrm{P}=1.000$ - the wet season) (Table 1).

Types and Populations of Insect Pests and their Natural Enemies Based on Direct Visual Observation.

Insect pests species population. Three dominant insect pests found in the rice field were white-backed planthopper, brown planthopper, and rice black bug. The white-backed planthopper (WBPH) populations appeared to fluctuate and did not differ between treatments, both in the dry and the wet seasons $(\mathrm{P}=$ 0.6089 - the dry season; $\mathrm{P}=0.1652$ - the wet season). This result was also seen in brown planthopper populations $(\mathrm{P}=0.8059$ - the dry season; $\mathrm{P}=0.4726$ the wet season). In the dry season, the rice black bug (RBB) population was high, but it did not differ between treatments $(\mathrm{P}=0.2619)$. In the wet season, the RBB population was significantly different between treatments $(\mathrm{P}=0.0078)$. The highest $\mathrm{RBB}$ population was observed in treatment D (Soybean) and the lowest was seen in treatment F (Wedelia trilobata (L.) - corn) (Table 1).

Types and populations of natural enemies. A total of 5 types of dominant natural enemies were found during the observation. The five natural enemies were spiders, Coccinella, Ophionea, Paederus, and Cyrtorhinus. Spiders were the most common natural enemy in the field. In the dry season and wet season, spider populations was high, however, it did not statistically different between treatments $(\mathrm{P}=0.8893$ - the dry season; $\mathrm{P}=0.2474$ - the wet season). The Coccinella population was fluctuated during the dry season, but there was no difference in the Coccinella population between treatments $(\mathrm{P}=0.5397$ - the dry season). In the wet season, the Coccinella population declined and did not differ between treatments $(\mathrm{P}=0.1621$ - the wet season). In both the dry and wet seasons, the Ophionea population was exceptionally low and there were no differences in Ophionea population between treatments $(\mathrm{P}=0.5049$ - the dry season; $\mathrm{P}=0.6051$ - the wet season). Paederus population has also fluctuated in the dry and wet seasons. In general, both in the dry season and wet season there were no differences in population between treatments $(\mathrm{P}=0.1839$ - the dry season; $\mathrm{P}=0.6294$ - the wet season). In the dry season, Cyrtorhinus populations were low, even in the wet season, there were no Cyrtorhinus populations. In addition, in both the dry and wet seasons there were no differences in Cyrtorhinus populations between treatments $(\mathrm{P}=0.6227$ - the dry season; $\mathrm{P}=0,000$ the wet season) (Table 2).

Tabel 1 . The average population of pest at each treatment in the dry and wet season

\begin{tabular}{ccccccccc}
\hline & \multicolumn{7}{c}{ Average populations of insect pest (individual/30 hills) } \\
\cline { 2 - 8 } Treatment & \multicolumn{7}{c}{ The wet season } \\
\cline { 2 - 8 } & YRSB & WBPH & BPH & RBB & YRSB & WBPH & BPH & RBB \\
\hline A & $1.09 \mathrm{ab}$ & $9.33 \mathrm{a}$ & $0.67 \mathrm{a}$ & $17.00 \mathrm{~b}$ & $0.00 \mathrm{a}$ & $7.33 \mathrm{a}$ & $0.00 \mathrm{a}$ & $3.33 \mathrm{~b}$ \\
$\mathrm{~B}$ & $0.42 \mathrm{~b}$ & $3.67 \mathrm{a}$ & $3.00 \mathrm{a}$ & $43.33 \mathrm{ab}$ & $0.00 \mathrm{a}$ & $3.33 \mathrm{ab}$ & $0.00 \mathrm{a}$ & $8.00 \mathrm{ab}$ \\
$\mathrm{C}$ & $1.08 \mathrm{ab}$ & $4.33 \mathrm{a}$ & $3.67 \mathrm{a}$ & $111.33 \mathrm{a}$ & $0.00 \mathrm{a}$ & $4.67 \mathrm{ab}$ & $0.00 \mathrm{a}$ & $7.00 \mathrm{ab}$ \\
$\mathrm{D}$ & $0.98 \mathrm{ab}$ & $10.00 \mathrm{a}$ & $3.00 \mathrm{a}$ & $20.33 \mathrm{~b}$ & $0.00 \mathrm{a}$ & $3.67 \mathrm{ab}$ & $0.00 \mathrm{a}$ & $10.67 \mathrm{a}$ \\
$\mathrm{E}$ & $1.18 \mathrm{ab}$ & $8.33 \mathrm{a}$ & $3.33 \mathrm{a}$ & $31.00 \mathrm{~b}$ & $0.00 \mathrm{a}$ & $6.33 \mathrm{a}$ & $0.33 \mathrm{a}$ & $9.33 \mathrm{ab}$ \\
$\mathrm{F}$ & $2.43 \mathrm{a}$ & $6.33 \mathrm{a}$ & $4.33 \mathrm{a}$ & $21.00 \mathrm{~b}$ & $0.00 \mathrm{a}$ & $6.00 \mathrm{a}$ & $0.00 \mathrm{a}$ & $1.00 \mathrm{c}$ \\
$\mathrm{G}$ & $1.33 \mathrm{ab}$ & $12.00 \mathrm{a}$ & $4.67 \mathrm{a}$ & $43.67 \mathrm{ab}$ & $0.00 \mathrm{a}$ & $1.33 \mathrm{~b}$ & $0.00 \mathrm{a}$ & $6.33 \mathrm{ab}$ \\
$\mathrm{H}$ & $2.19 \mathrm{a}$ & $10.33 \mathrm{a}$ & $2.33 \mathrm{a}$ & $29.67 \mathrm{~b}$ & $0.00 \mathrm{a}$ & $5.33 \mathrm{a}$ & $0.00 \mathrm{a}$ & $7.67 \mathrm{ab}$ \\
$\mathrm{I}$ & $1.72 \mathrm{ab}$ & $6.67 \mathrm{a}$ & $3.00 \mathrm{a}$ & $24.00 \mathrm{~b}$ & $0.00 \mathrm{a}$ & $6.67 \mathrm{a}$ & $0.00 \mathrm{a}$ & $5.33 \mathrm{ab}$ \\
\hline
\end{tabular}

YRSB: yellow rice stem borer; WBPH: white-backed planthopper; BPH: brown planthopper; RBB: rice black bug; (A) Sesamum orientale (L.) (Pedaliaceae); (B) Wedelia trilobata (L.) (Asteraceae); (C): Corn; (D) Soybean; (E) Sesamum orientale (L.) - corn; (F) Wedelia trilobata (L.) - corn; (G) Sesamum orientale (L.) - soybean; (H) Wedelia trilobata (L.) - soybean; (I) Control (without flowering plants and crops). Number followed with the same letter in the same column at each treatment showed not significantly different in DMRT with 5\% significance level. 


\section{Types and Populations of Insect Pests and Natural Enemies Based on Sweeping and Trapping.}

Insects caught by sweep net. Based on the number of insects caught by sweep net in the dry season, the population of neutral insect was higher than the predators, parasitoid, and insect pest. However, the populations of these insects did not statistically different between treatments $(\mathrm{P}=0.7205 ; \mathrm{P}=0.6223 ; \mathrm{P}=0.5712$; $\mathrm{P}=0.5811$ ) (Figure 1).

Insects caught by yellow pan traps. Based on the number of insects caught using yellow pan traps conducted in the dry season, it appeared that the population of predator insect groups was higher than neutral insects, parasitoids, and pests. However, the insect populations did not statistically different between treatments $(\mathrm{P}=0.4339 ; \mathrm{P}=0.9334 ; \mathrm{P}=0.1536$; $\mathrm{P}=0.6413$ ) (Figure 2).

Insect caught by pitfall traps. Based on the number of insects caught using pitfall traps conducted in the dry season, it appeared that the population of predator insect groups was higher than neutral insects, parasitoids, and pests. However, the insect populations did not statistically different between treatments $(\mathrm{P}=0.7772 ; \mathrm{P}=0.8175 ; \mathrm{P}$ $=0.6170 ; \mathrm{P}=0.4726)$ (Figure 3 ).
Level of Parasitism. The parasitoid level of parasitism in the dry season was ranged from 47.32 to $50.47 \%$, and the parasitism level did not differ among treatments at all observation times (Anagrus: $\mathrm{P}=0.4386$; Oligosita : $\mathrm{P}=0.9288 ;$ Anagrus + Oligosita $: \mathrm{P}=0.8738)($ Table $3)$. The results of trapping by brown planthopper eggs carried out in the wet season showed that, the parasitoid level of parasitism was ranged from 36.37 to $53.92 \%$, and the level of parasitism was different among treatments (Anagrus: $\mathrm{P}=0.3927$; Oligosita: $\mathrm{P}=0.1660$; Anagrus + Oligosita: $\mathrm{P}=0.0341)$. The highest parasitism level was observed in the treatment B (Wedelia trilobata (L.) (Asteraceae)), while the lowest parasitism level was observed in the treatment I (Control) (Table 3). Other information from all observations showed that the Oligosita parasitoid has a better performance compared to the Anagrus parasitoid in parasitizing the brown planthopper eggs (Table 3).

Rice Yields. Yields of Mekongga rice varieties in all treatments were not significantly different compared to controls in the dry and the wet seasons. This showed that ecological engineering by planting flower plants and crops has no significant effect on increasing rice yield (Table 4).

Tabel 2.The average population of natural enemies at each treatment in the dry and wet season

\begin{tabular}{|c|c|c|c|c|c|c|c|c|c|c|}
\hline \multirow{3}{*}{ Treatment } & \multicolumn{10}{|c|}{ Average populations of natural enemies (individual $/ 30$ hills) } \\
\hline & \multicolumn{5}{|c|}{ The dry season } & \multicolumn{5}{|c|}{ The wet season } \\
\hline & Spider & $\mathrm{Coc}$ & Oph & Pae & Cyr & Spider & $\mathrm{Coc}$ & Oph & Pae & Cyr \\
\hline A & $25.67 \mathrm{a}$ & $11.33 \mathrm{a}$ & $3.67 \mathrm{a}$ & $26.67 \mathrm{a}$ & $2.33 \mathrm{a}$ & $24.33 \mathrm{a}$ & $1.67 \mathrm{ab}$ & $0.00 \mathrm{a}$ & $13.00 \mathrm{a}$ & $0.00 \mathrm{a}$ \\
\hline $\mathrm{B}$ & $31.33 \mathrm{a}$ & $6.67 \mathrm{a}$ & $5.67 \mathrm{a}$ & $21.67 \mathrm{ab}$ & $2.33 \mathrm{a}$ & $26.33 \mathrm{a}$ & $3.33 \mathrm{a}$ & $0.00 \mathrm{a}$ & $7.00 \mathrm{a}$ & $0.00 \mathrm{a}$ \\
\hline $\mathrm{C}$ & $29.00 \mathrm{a}$ & $10.00 \mathrm{a}$ & $2.00 \mathrm{a}$ & $18.00 \mathrm{ab}$ & $8.00 \mathrm{a}$ & $20.33 \mathrm{a}$ & $4.00 \mathrm{a}$ & $0.00 \mathrm{a}$ & $6.67 \mathrm{a}$ & $0.00 \mathrm{a}$ \\
\hline $\mathrm{D}$ & $29.33 \mathrm{a}$ & $8.00 \mathrm{a}$ & $5.33 \mathrm{a}$ & $22.33 \mathrm{ab}$ & $3.33 \mathrm{a}$ & $22.67 \mathrm{a}$ & $2.00 \mathrm{ab}$ & $0.00 \mathrm{a}$ & $9.33 \mathrm{a}$ & $0.00 \mathrm{a}$ \\
\hline $\mathrm{E}$ & $28.67 \mathrm{a}$ & $10.33 \mathrm{a}$ & $3.00 \mathrm{a}$ & $18.33 \mathrm{ab}$ & $7.33 \mathrm{a}$ & $27.33 \mathrm{a}$ & $1.00 \mathrm{~b}$ & $0.00 \mathrm{a}$ & $11.67 \mathrm{a}$ & $0.00 \mathrm{a}$ \\
\hline $\mathrm{F}$ & $27.00 \mathrm{a}$ & $10.00 \mathrm{a}$ & $5.67 \mathrm{a}$ & $23.67 \mathrm{ab}$ & $0.67 \mathrm{a}$ & $20.67 \mathrm{a}$ & $2.67 \mathrm{ab}$ & $0.00 \mathrm{a}$ & $10.00 \mathrm{a}$ & $0.00 \mathrm{a}$ \\
\hline G & $29.00 \mathrm{a}$ & $8.67 \mathrm{a}$ & $3.33 \mathrm{a}$ & $15.67 \mathrm{~b}$ & $0.33 \mathrm{a}$ & $25.00 \mathrm{a}$ & $3.33 \mathrm{a}$ & $0.00 \mathrm{a}$ & $7.33 \mathrm{a}$ & $0.00 \mathrm{a}$ \\
\hline $\mathrm{H}$ & $30.33 \mathrm{a}$ & $8.00 \mathrm{a}$ & $4.33 \mathrm{a}$ & $17.33 \mathrm{~b}$ & $7.33 \mathrm{a}$ & $26.00 \mathrm{a}$ & $3.33 \mathrm{a}$ & $0.00 \mathrm{a}$ & $9.33 \mathrm{a}$ & $0.00 \mathrm{a}$ \\
\hline I & $30.33 \mathrm{a}$ & $8.33 \mathrm{a}$ & $5.33 \mathrm{a}$ & $22.00 \mathrm{ab}$ & $5.33 \mathrm{a}$ & $23.67 \mathrm{a}$ & $3.67 \mathrm{a}$ & $0.00 \mathrm{a}$ & $5.67 \mathrm{a}$ & $0.00 \mathrm{a}$ \\
\hline
\end{tabular}

(A) Sesamum orientale (L) (Pedaliaceae); (B) Wedelia trilobata (L) (Asteraceae); (C) Corn; (D) Soybean; (E) Sesamum orientale (L) - corn; (F) Wedelia trilobata (L) - corn; (G) Sesamum orientale (L) - soybean; (H) Wedelia trilobata (L) - soybean; (I) Control (without flowering plants and crops). (Coc) Coccinella; (Oph) Ophonea; (Pae) Paederus; (Cyr) Cyrtorhinus. Number followed with the same letter in the same column at each treatment showed not significantly different in DMRT with 5\% significance level. 


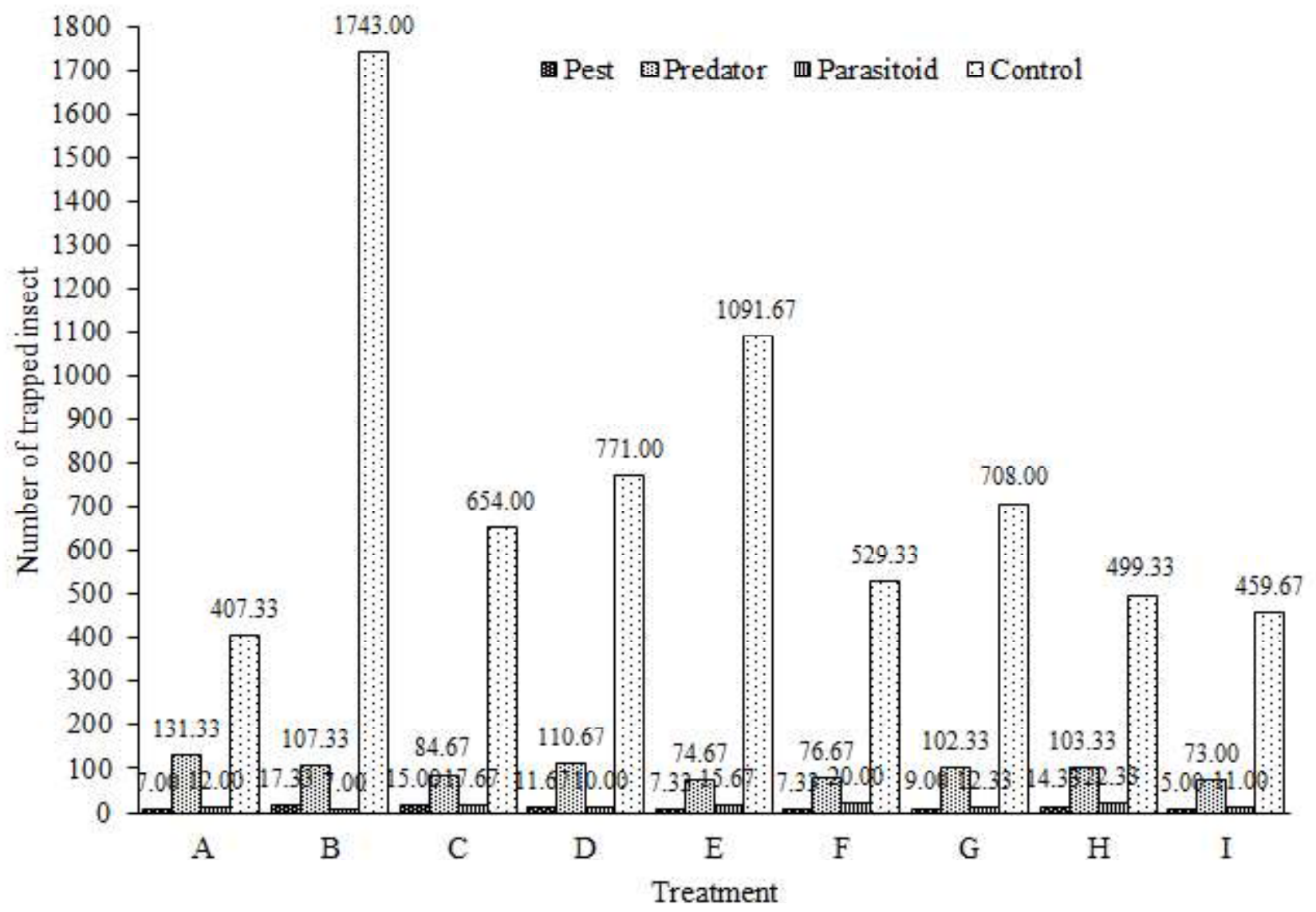

Figure 1. Number of insect caught by sweep net. (A) Sesamum orientale (L.) (Pedaliaceae); (B) Wedelia trilobata (L.) (Asteraceae); (C) Corn; (D) Soybean; (E) Sesamum orientale (L.) - corn; (F) Wedelia trilobata (L.) - corn; (G) Sesamum orientale (L.) - soybean; (H) Wedelia trilobata(L.) - soybean; (I) Control (without flowering plants and crops).

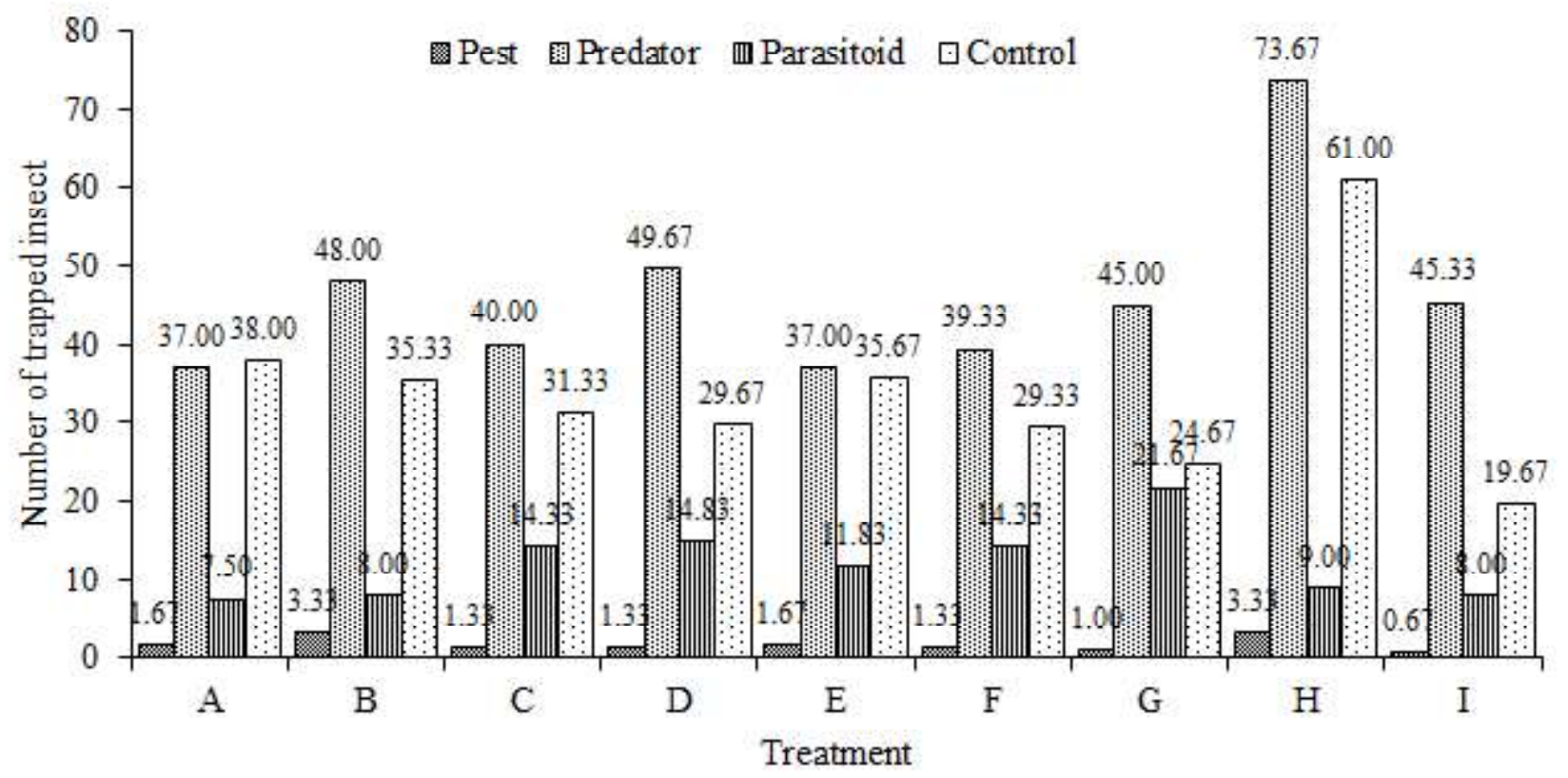

Figure 2. The number of insects caught by yellow pan traps. (A) Sesamum orientale (L.) (Pedaliaceae); (B) Wedelia trilobata (L.) (Asteraceae); (C) Corn; (D) Soybean; (E) Sesamum orientale (L.) - corn; (F) Wedelia trilobata (L.) - corn; (G) Sesamum orientale (L.) - soybean; (H) Wedelia trilobata (L) soybean; (I) Control (without flowering plants and crops). 
Based on the results of this study, it was seen that ecological engineering by planting flowers and crops did not show a consistent impact on the rice fields for controlling the populations of brown planthopper, white- backed planthopper, and rice black bug, and even had no significant effect on yellow rice stem borer. Ecological engineering by planting flowers and crops on paddy fields did not increase the rice yields and has not level of

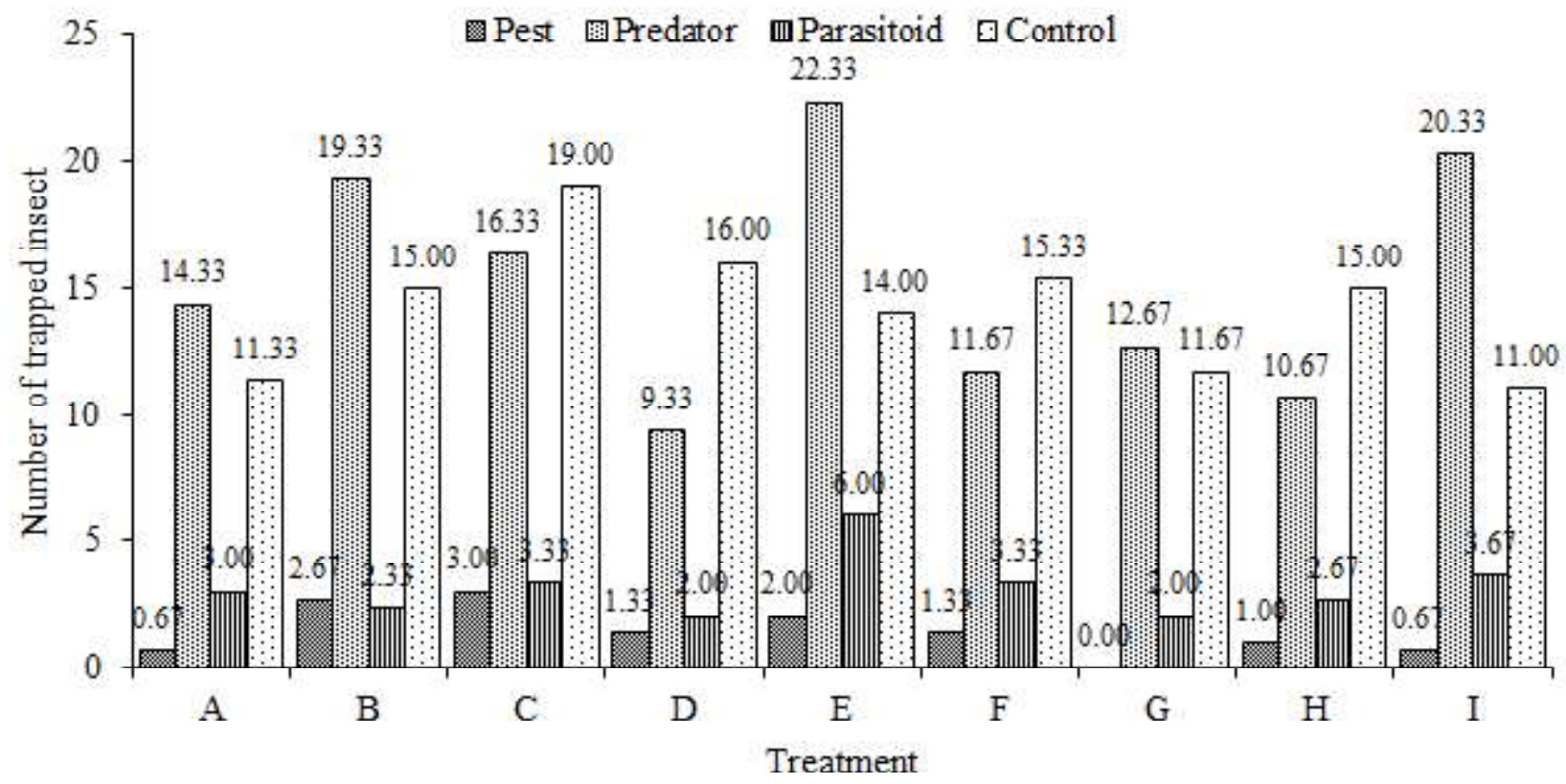

Figure 3. The number of insects caught by pitfall traps. (A) Sesamum orientale (L.) (Pedaliaceae); (B) Wedelia trilobata (L.) (Asteraceae); (C) Corn; (D) Soybean; (E) Sesamum orientale (L.) - corn; (F) Wedelia trilobata (L.) - corn, (G) Sesamum orientale (L.) - soybean; (H) Wedelia trilobata (L.) - soybean; (I) Control (without flowering plants and crops).

Tabel 3. The average parasitism level of brown planthopper egg by Anagrus and Oligosita at each treatment in the dry and wet season

\begin{tabular}{ccccccc}
\hline & \multicolumn{5}{c}{ The average parasitism level of brown planthopper egg (\%) } \\
\cline { 2 - 7 } Treatment & \multicolumn{3}{c}{ The dry season } & \multicolumn{3}{c}{ The wet season } \\
\cline { 2 - 7 } & Anagrus & Oligosita & Anagrus + Oligosita & Anagrus & Oligosita & Anagrus + Oligosita \\
\hline A & $3.38 \mathrm{a}$ & $44.07 \mathrm{a}$ & $47.45 \mathrm{a}$ & $14.70 \mathrm{a}$ & $32.73 \mathrm{a}$ & $47.43 \mathrm{ab}$ \\
$\mathrm{B}$ & $3.61 \mathrm{a}$ & $45.34 \mathrm{a}$ & $48.95 \mathrm{a}$ & $17.85 \mathrm{a}$ & $36.06 \mathrm{a}$ & $53.92 \mathrm{a}$ \\
$\mathrm{C}$ & $2.77 \mathrm{a}$ & $44.55 \mathrm{a}$ & $47.32 \mathrm{a}$ & $13.95 \mathrm{a}$ & $28.36 \mathrm{ab}$ & $42.31 \mathrm{bc}$ \\
$\mathrm{D}$ & $2.69 \mathrm{a}$ & $45.99 \mathrm{a}$ & $48.68 \mathrm{a}$ & $13.24 \mathrm{a}$ & $31.22 \mathrm{ab}$ & $44.47 \mathrm{bc}$ \\
$\mathrm{E}$ & $3.84 \mathrm{a}$ & $44.87 \mathrm{a}$ & $48.72 \mathrm{a}$ & $13.58 \mathrm{a}$ & $29.29 \mathrm{ab}$ & $42.86 \mathrm{bc}$ \\
$\mathrm{F}$ & $3.07 \mathrm{a}$ & $45.75 \mathrm{a}$ & $48.82 \mathrm{a}$ & $13.34 \mathrm{a}$ & $32.82 \mathrm{a}$ & $46.16 \mathrm{ab}$ \\
$\mathrm{G}$ & $3.05 \mathrm{a}$ & $46.76 \mathrm{a}$ & $49.81 \mathrm{a}$ & $17.45 \mathrm{a}$ & $30.31 \mathrm{ab}$ & $47.75 \mathrm{ab}$ \\
$\mathrm{H}$ & $4.78 \mathrm{a}$ & $44.48 \mathrm{a}$ & $49.26 \mathrm{a}$ & $13.33 \mathrm{a}$ & $31.13 \mathrm{ab}$ & $44.46 \mathrm{bc}$ \\
$\mathrm{I}$ & $4.01 \mathrm{a}$ & $46.46 \mathrm{a}$ & $50.47 \mathrm{a}$ & $12.18 \mathrm{a}$ & $24.19 \mathrm{~b}$ & $36.37 \mathrm{c}$
\end{tabular}

(A) Sesamum orientale (L.) (Pedaliaceae); (B) Wedelia trilobata (L) (Asteraceae); (C) Corn; (D) Soybean; (E) Sesamum orientale (L.) - corn; (F) Wedelia trilobata (L.) - corn; (G) Sesamum orientale (L.) - soybean; (H) Wedelia trilobata (L.) - soybean; (I) Control (without flowering plants and crops). Number followed with the same letter in the same column at each treatment showed not significantly different in DMRT with 5\% significance level. 
parasitism of parasitoids. The parasitism level of the parasitoids was ranged between $47.32-50.47 \%$ in the dry season and $36.37-53.92 \%$ in the wet season. Based on the insect caught using sweep net, yellow pan traps, pitfall traps, and direct observations at each observation time, the insect population was high at the beginning and was decreasing along the plant growth stage. Whereas the neutral insect population was dominated from the beginning of planting to maximum tillers stage and then followed by the predator insect population. However, in general, all predators, neutral insects, parasitoids, and pest populations did not statisstically different among treatments. This means that the ecological engineering had not yet given impact on pests, natural enemies, and rice yields. This condition was caused by several factors. First, the ecological engineering research location was not isolated and was on the same level as a non-ecological engineering farm. Non-ecological engineering farms were very intensive in using insecticides to control existing pests in their crops. In one planting season, farmers can apply 8-12 times of insecticides. With the intensive use of insecticides on this farmer's field, insects and flowering plants and crops that were in ecological engineering research sites were exposed to insecticides both by their smell and by particles carried by the wind. The smell of insecticide will prevent parasitoids and predators to find flowering plants and crops. Flowering plants provide additional feed (pollen and nectar) that support the development of natural enemies and crops are shelters or refugees for natural enemies (Baehaki, 2005; Sivinski et al., 2011). In contrast to insect pests, the smell of insecticides can inhibit the process of finding a host (rice plant). Wind-borne insecticide particles will arrive at the study site and stick to all treatments in both flowering and crops. Predators and parasitoids can be in contact with insecticides through their host, direct contact, or by digesting nectar and pollen in flowers (Fernandes $e t$ al., 2010).

Secondly, this ecological engineering research was only carried out in 1 year ( 2 planting seasons, the dry season, and the wet season). The duration of the implementation of ecological engineering was too short so that it had not provided an opportunity for natural enemies to adapt and develop in ecological engineering research locations and demonstrate their performance in controlling rice pests. Edpuganti \& Rajan (2018) reported that ecological engineering by planting flowers

Tabel 4. The rice yields at each treatment in the dry and wet season

\begin{tabular}{ccc}
\hline \multirow{2}{*}{ Treatment } & \multicolumn{2}{c}{ Average rice yields $(\mathrm{kg} / 0.25 \mathrm{ha})$} \\
\cline { 2 - 3 } & The dry season & The wet season \\
\hline A & $1377.67 \mathrm{a}$ & $1321.42 \mathrm{a}$ \\
B & $1307.33 \mathrm{a}$ & $1352.58 \mathrm{a}$ \\
C & $1305.33 \mathrm{a}$ & $1362.58 \mathrm{a}$ \\
D & $1336.00 \mathrm{a}$ & $1418.92 \mathrm{a}$ \\
E & $1188.00 \mathrm{a}$ & $1495.33 \mathrm{a}$ \\
F & $1395.00 \mathrm{a}$ & $1304.75 \mathrm{a}$ \\
G & $1240.33 \mathrm{a}$ & $1363.42 \mathrm{a}$ \\
H & $1315.33 \mathrm{a}$ & $1432.25 \mathrm{a}$ \\
I & $1377.33 \mathrm{a}$ & $1421.42 \mathrm{a}$ \\
\hline
\end{tabular}

(A) Sesamum orientale (L.) (Pedaliaceae); (B) Wedelia trilobata (L.) (Asteraceae); (C) Corn; (D) Soybean; (E) Sesamum orientale (L.) - corn; (F) Wedelia trilobata (L.) - corn; (G) Sesamum orientale (L.) - soybean; (H) Wedelia trilobata (L.) - soybean; (I) Control (without flowering plants and crops). Number followed with the same letter in the same column at each treatment showed not significantly different in DMRT with 5\% significance level. 
in their institution was succeeded in increasing the population of natural enemies and was able to effectively control pests after maintaining the ecologically engineered rice fields for 4 years.

Another factor is the selection of flowering plants and the combination of crops used in ecological engineering treatments was suspected to be incompatible, so additional research was needed to obtain suitable plants. This phenomenon has been reported by Meiadi et al. (2015) that Arachis pintoi (Krapov. \& W.C. Greg.) and Ageratum conyzoides (Linn.) were incompatibly combined as refugia plants because they negative effect on the parasitism level of Bactrocera carambolae (Drew \& Hancock). Efforts to find suitable plants to support and supplement sesame (Sesamum indicum) as flowering plants in rice agroecosystems have also been carried out by Zhu et al. (2013) and found that Emilia sonchifolia and Impatiens balsamina are two weed plants that can complement the presence of sesame in increasing the parasitoid population of Anagrus plant hopper eggs in the rice plantations.

Related to the selection of flowering plants and crops used in this study, the basic idea was that ecological engineering will give 2 benefits, ecologically and economically. Ecological engineering can restore ecosystem instability and economically, give benefit to the farmers. The benefits for farmers are obtained from the planting of crops. This is certainly different from that done by other researchers who study ecological engineering using only flowering plants or crops (Kurniawati, 2015; Kurniawati \& Martono, 2015; Baehaki et al., 2016; Amanda, 2017; Edpuganti \& Rajan, 2018; Erdiansyah et al., 2018; Erdiansyah \& Putri, 2018; Sepe \& Djafar, 2018; Septariani et al., 2019; Allifah et $a l ., 2019)$. Thus, to gain the double impact, it is better to choose flowering plants that have the function and role of these plants in the environment (Kurniawati \& Martono, 2015) and crops that have added value for farmers.

\section{CONCLUSION}

Planting flowering plants and various crops on the rice field not significant impact on the types and populations of insect pests, natural enemies, and rice yields. This ecological engineering had not yet seen an impact in stabilizing the population of useful insects (neutral, predators, parasitoids) at each of the rice plant growth stages.

\section{ACKNOWLEDGEMENTS}

We would like to acknowledge the Head of the Indonesian Center for Rice Research for providing research funding. We also thank the team of researchers and technicians of the Plant Protection Department, the Indonesian Center for Rice Research in SukamandiSubang, West Java, who assisted in conducting the research.

\section{REFERENCES}

Allifah ANAF, Rosmawati T, \& Jamdin Z. 2019. Refugia ditinjau dari konsep gulma pengganggu dan upaya konservasi musuh alami. Biosel. 8(1): 82-89.

Altieri MA, Nicholls CI, \& Fritz MA. 2005. Manage Insect on your Farm: a Guide to Ecological Strategies. Sustainable Agricultre Network, Beltsville.

Amanda UD. 2017. Pemanfaatan tanaman refugia untuk mengendalikan hama dan penyakit tanaman padi. Buletin IKATAN. 7(2): 29-45.

Amzah B, Jajuli R, Jaafar NAI, Jamil SZ, Hamid SNAA, Zulkfili NI, Ismail NA, Kadir AA, Ariff EEE, \& Baki R. 2018. Application of ecological engineering to increase arthropod's diversity in rice ecosystem. Malays. Appl. Biol. 47(5): 1-7.

Baehaki SE, Arifin K, \& KL Heong. 2003. Perbaikan pengendalian hama terpadu (PHT) berdasar pemahaman biodiversitas arthropoda pada berbagai pola pertanaman padi. Laporan Hasil Penelitian. Balai Penelitian Tanaman Padi Bekerjasama dengan Badan Penelitian dan Pengembangan Pertanian Proyek Pengkajian Teknologi Pertanian Partisipatif Pusat/PAATP.

Baehaki SE \& Djuniadi D. 2004. Peningkatan teknologi pengendalian hama terpadu dalam kawasan system integrasi pertanaman padi dan palawija (SIP3) sebagai metode baru pengembangan pertanian modern. Laporan Hasil Penelitian. Proyek Pengkajian Teknologi Pertanian Partisipatif Pusat/PAATP Badan Penelitian dan Pengembangan Pertanian Kerjasama dengan P.T. Bayer Indonesia.

Baehaki SE. 2005. Perbaikan teknik pengendalian hama terpadu pada sistem integrasi pertanaman padi dan palawija. In: Hermanto \& Sunihardi (Eds.). Risalah Seminar 2004 Puslitbang Tanaman 
Pangan. pp. 137-142. Pusat Penelitian dan Pengembangan Tanaman Pangan. Badan Penelitian dan Pengembangan Pertanian. Bogor.

Baehaki SE, Irianto NBE, \& Widodo SW. 2016. Rekayasa ekologi dalam perspektif pengelolaan tanaman padi terpadu. Iptek Tanaman Pangan. 11(1): 19-34.

Balai Besar Peramalan Organisma Pengganggu Tumbuhan (BBPOPT). 2010. Luas serangan OPT Utama Pada Tanaman Padi Tahun 2010. Laporan Tahunan T.A 2012. Balai Besar Peramalan Organisma Pengganggu Tumbuhan. Jawa Barat.

Debach P. 1973. Biological Control of Insect Pests and Weeds. Chapman and Hall Ltd., London.

Direktorat Jenderal Tanaman Pangan (Dirjentan). 2007. Informasi Perkembangan Serangan OPT Padi Tahun 2006, Tahun 2005 dan Rerata 5 Tahun (2000-2004). Direktorat Jenderal Tanaman Pangan Direktorat Perlindungan Tanaman. Jakarta.

Edpuganti LS \& Rajan SJ. 2018. Ecological engineering for sustainable agriculture: simple concept with greater impact. IJSRP. 8(2): 123-125.

Erdiansyah I, Ningrum DRK, \& Damanhuri. 2018. Pemanfaatan tanaman bunga marigold dan kacang hias terhadap populasi arthropoda pada tanaman padi sawah. Agriprima. 2(2): 117-125.

Erdiansyah I \& Putri SU. 2018. Implementasi tanaman refugia dan peran serangga pada tanaman padi sawah (Oryza sativa L.) di Kabupaten Jember. Agrin. 22(2): 123-131.

Fernandes FL, Bacci L, \& Fernandes MS. 2010. Impact and selectivity of insecticides to predators and parasitoids. EntomoBrasilis. 3(1): 1-10.

Herlinda S. 2000. Analisis komunitas artropoda predator penghuni lansekap persawahan di daerah Cianjur, Jawa Barat. Disertasi. Institut Pertanian Bogor, Bogor.

Kartohardjono A. 2011. Penggunaan musuh alami sebagai komponen pengendalian hama padi berbasis ekologi. Pengembangan Inovasi Pertanian. 4(1): 29-46.

Kurniawati N. 2015. Keragaman dan kelimpahan musuh alami hama pada habitat padi yang dimanipulasi dengan tumbuhan berbunga. Ilmu Pertanian. 18(1): 31-36.
Kurniawati N \& Martono E. 2015. Peran tumbuhan berbunga sebagai media konservasi artropoda musuh alami. JPTI. 19(2): 53-59.

Kusprayogie Y, Darmadi D, \& Sujiono. 2016. Prakiraan serangan OPT Utama Padi MT. 2016/2017. Majalah Peramalan OPT. 15(2): 5-11.

Lokesh S, Muthukrishnan N, Ganapathy N, Kannan Bapu JR, \& Somasundaram E. 2017. Ecological engineering cropping methods enhance Coccinellids and suppress aphids Aphis gossypii (Glover) in blackgram. J. Entomol. Zool. Stud. 5(3): 1288-1294.

Meiadi TML, Himawan T, \& Karindah S. 2015. Pengaruh Arachis pintoi dan Ageratum conyzoides terhadap tingkat parasitasi parasitoid lalat buah pada pertanaman belimbing. J. HPT. 3(1): 44-53.

Ngatimin SNA. 2002. Potensi tumbuhan berbunga sebagai sumber pakan tambahan untuk meningkatkan kebugaran parasitoid Diadegma semiclausum Hellen (Hymenoptera: Ichneumonidae). Thesis. Institut Pertanian Bogor, Bogor.

SAS Institute. 1990. SAS/STAT User's Guide, Version 6. Fourth Edition. Volume 2. SAS Institute Inc, North Carolina.

Sepe M \& Djafar MI. 2018. Perpaduan tanaman refugia dan tanaman kubis pada berbagai pola tanam dalam menarik predator dan parasitoid dalam penurunan populasi hama. Agrovital. 3(2): 5559.

Septariani DN, Herawati A, \& Mujiyo. 2019. Pemanfaatan berbagai tanaman refugia sebagai pengendali hama alami pada tanaman cabai (Capsicum annum L.). PRIMA. 3(1): 1-9.

Sivinski J, Wahl D, Holler T, Al Dobai S, \& Sivinski R. 2011. Conserving natural enemies with flowering plants: estimating floral attractiveness to parasitic Hymenoptera and attraction's relationship to flower and plant morphology. Biol. Control. 58(3): 208-214.

Widiarta IN, Kusdiaman D, \& Suprihanto. 2006. Keragaman arthropoda pada padi sawah dengan pengelolaan tanaman terpadu. J.HPT Tropika. 6(2): 61-69. 
Yaherwandi, Manuwoto S, Buchori D, Hidayat P, \& Prasetyo LB. 2007. Keanekaragaman Hymenoptera parasitoid pada struktur lanskap pertanian berbeda di daerah aliran sungai (DAS) Cianjur, Jawa Barat. J. HPT. Tropika. 7(1): 1020.
Zhu PY, Gurr GM, Lu ZH, Heong KL, Chen GH, Zheng XS, Xu HX, \& Yang YJ. 2013. Laboratory screening supports the selection of sesame (Sesamum indicum) to enhance Anagrus spp. parasitoids (Hymenoptera: Mymaridae) of rice planthoppers. Biol. Control. 64(1): 83-89. 